\title{
Human Capital in the Formation of Efficiency of Enterprises Activity
}

\author{
PhD Svitlana Hryvkivska ${ }^{1}$, Assoc. Prof., PhD Nataliia Polishchuk ${ }^{2}$, Assoc. Prof., PhD \\ Iryna Salkova ${ }^{3}$, Assoc. Prof., PhD Lesia Kucher ${ }^{4}$
}

\begin{abstract}
The purpose of the article is to determine the role of human capital in the functioning of machine-building enterprises, based on the peculiarities of the formation of labor costs for hired workers in relation to the dynamics of capital expenditures (fixed assets) in order to increase revenue (revenues) from sales of products.

The method of correlation-regression analysis has been used, which has revealed the high density of communication, to construct the equation of the dependence of labor costs and capital expenditures (fixed assets) on income (revenue) from sales of products. Using the method of analysis of the functioning environment, according to the machine-building enterprises of the region, the coefficients of covering income (revenue) from the sale of capital expenditures (fixed assets) and labor costs for hired workers, formed the ability to find the indicators of capital expenditure (fixed assets). according to given economic entities the possibility of increasing the income (revenue) from sales of products.

The directions of strengthening the development of human capital, in particular, by increasing the cost of capital (fixed assets) of machine-building enterprises in the region, which will increase their profitability, are revealed.
\end{abstract}

Key words: human capital, physical capital (fixed assets), income (revenue) from sales of products, enterprises, correlation-regression analysis, analysis of the functioning environment.

\section{Introduction}

The development of a modern economy is possible under the conditions of human capital strengthening through new approaches formation to the use of intelligence, knowledge and health of an individual. For our country, the value of human capital has not yet become sufficiently significant, as there is a departure of personnel abroad, and the economy is in decline. Therefore, human capital development can be estimated only on the basis of wage bill and volume of sales.

The current state of the education sector adds problems, as there are significant problems regarding the recognition of Ukrainian standards and the possibility of their use in modern practice. Taking into consideration all difficulties mentioned above, we suggest conducting research on the example of one of the human capital factors - wages in conjunction with physical capital (expenditures on fixed assets) and income (revenue) from sales of products in the example of 22 machine-building enterprises of the Vinnytsia region.

Human capital concept began to be formed from the early 60's of the 20th century, as a factor in quality work through the development of intelligence, knowledge and health. As a result, Western scholars, including Nobel laureates, have devoted considerable attention

\footnotetext{
${ }^{1}$ Mykolayiv National University named after V. Sukhomlinsky, Mykolayiv, Ukraine.

2 Vinnytsia Finance and Economics University, Ukraine.

3 Vinnytsia National Agrarian University, Ukraine.

${ }^{4}$ Kharkiv National Agrarian University named after V. V. Dokuchayev, Kharkiv, Ukraine.
} 
to the development of an innovative economy through human capital, such as: O. Amosov [1], G. Becker [2], R. Solou [3], T. Schultz [4], L. Krivenko [5], S. Kuznets [6], R. Lucas [7], P. Romer [8], L. Fedulova [9], G. Yalovy [12], and others. Relevance of this topic is confirmed by the last decision of Nobel Committee on awarding the prize for 2018 P. Romer, who identified the priority role of human capital in the development of technological innovation [8].

Particular attention deserves such authors' work as: O. Amosov and A. Degtyar, who reveal the peculiarities of human capital formation under an innovative economy condition. The authors state that "in modern conditions, human capital is becoming the main factor of innovation production, and the creative potential of the person, his knowledge and professionalism are put on the forefront of technical and economic progress" [1]. In their turn, L. Krivenko, S. Ovcharenko [5] investigates the actual questions main aspects of human capital development theory and methodology and the role of the human factor in improving the country's competitiveness.

The researchers identify the main obstacles and contradictions in the development of human capital in Ukraine and substantiate the need to develop a qualitatively new paradigm for the formation, efficient use, reproduction and human capital development of innovative type.

L. Fedulova and A. Prysyazhnyuk [9] are carried out their studies in the same aspect, which prove the necessity of intensifying the influence of the human factor on the country's innovative development, as well as the fact that the intellectual potential of people is at a high level, but the role of the state in creating the environment is ineffective for its implementation. They are offered ways to improve the human innovation factor in the social and economic development of the country, taking into account international experience.

G. Yalovyi [12] is right stating that the theory of human capital is a methodological basis for the management of innovation activity, which will ensure Ukraine's competitiveness under the conditions of globalization.

S. Bay and A. Rozman in their studies substantiated the ways to increase the value of the enterprise to meet the needs of society based on the activation of the human factor and proposed algorithm for implementing a value-oriented model of human capital management of the enterprise. They emphasize that the quality of personnel is one of the main factors determining the development of the enterprise pace and the growth of its value in general [13].

J. Drábek, S. Lorincová and J. Javorčíková point out, that human capital plays a crucial role in increasing the productivity and output of an organisation. In their studies, to be an example of a particular enterprise they proved the effectiveness of investment in human resources through the use of measurable and immeasurable indicators of efficiency of investment in human resources [14].

C. Diebolt and R. Hippe studied the relationship between historical human capital and current economic indicators in the European regions. The results show that human capital is the most significant historical factor related to current patent applications per capita and current GDP per capita [15].

I. Kopytova and A. Zelinska in their work developed a system of criteria for assessing the effectiveness of management staff [16]. A. Burkovska and M. Romanchyk consider the 
peculiarities of strategic management of human resources as strategic potential basis, which affects the competitiveness of the enterprise, determines the directions of its development [17].

M. Kowalewski investigates human capital as an important factor in the country's economic development under the physical development of society context [18].

Human capital influence on the formation of enterprise efficiency of the various sectors of different countries economy are explored by J. Xu, B. Wang, A. Kucharčíková and also by M. Mičiak [19-21].

Problematic aspects of investing in human capital under the context of ensuring profitability production and sustainable development are explored in their writings M. Zhang, X. Zou and L.g Sha, A. MacDonald [22], A. Clarke, L. Huang and M. M. Seitanidi [23], F. J. Garrigos-Simon, M. D. Botella-Carrubi and T. F. GonzalezCruz [24], A. Kucharčíková, M. Mičiak and M. Hitka [25].

At the same time, there is a need to identify ways to strengthen human capital, starting with the formation of a sufficient wage level of wage earners in the context of optimizing the cost of physical capital and increasing revenue (income) from sales of products.

\section{Materials and Methods}

The purpose of the article is to evaluate the impact of human capital on the machine-building enterprises effectiveness formation in the context of their labor costs for hiring employees through the relationship with physical capital (capital expenditure (fixed assets) and financial results of economic entities (income statement (proceeds from sales of products).

This article is based on the financial statements: Form 1-to "Consolidated Balance Sheet (Statement of Financial Position)" and Form 2-to "Consolidated Statement of Financial Results (comprehensive income Statement)" of the machine-building enterprises of the Vinnytsia region.

Using the analysis method of the functioning environment, it was possible to distinguish human capital as the main component of the functioning of machine-building enterprises. The correlation-regression method allowed to conduct research on the impact of enterprise performance indicators in the context of the value of human capital relative to the cost of capital and the amount of income (revenue) from products sales.

\section{Results}

Human capital formation is the main task of modern society the formation. It is proved that the greatest challenges that the global economy must solve is the improvement of the environment and the formation of human capital.

This is an additional chance for Ukraine to take part in the processes of preventing the destruction of its own economy, which pace has become disastrous in recent years, since environmental disruptions have accumulated since the planning and administrative system, and the outflow of human capital in more successful countries has the potential to increase. The feature of the national economy of the state is the presence of a significant amount of physical capital, which in most cases represents the production capacity of various 
enterprises.

If we analyze the usual region of Ukraine, which is Vinnitsa region is, then the bias in the agrarian-industrial sector is clearly expressed: the advantage of agriculture in the possibilities to develop agricultural machinery. As a result, at present, in the conditions of the decline of the domestic industry, machine-building in the regions similar to the Vinnytsia region is in difficult times.

We suggest to analyze the possibilities of human capital development in the context of physical capital of machine-building enterprises of Vinnytsia region [10], based on the existing trends in the economy of the region (Table 1).

Table 1: Capital expenditures (fixed assets) and wage labor costs in the context of income (revenue) from products sales

\begin{tabular}{|c|c|c|c|c|c|c|}
\hline № & Enterprise & $\begin{array}{l}\text { Capital } \\
\text { expenditu- } \\
\text { res (main } \\
\text { assets) (C), } \\
\text { ths. UAH }\end{array}$ & \begin{tabular}{|l|} 
Labor \\
costs \\
(L), \\
ths. \\
UAH \\
\end{tabular} & $\begin{array}{l}\text { Income from } \\
\text { realization of } \\
\text { production } \\
(Y) \text {, ths. } \\
\text { UAH }\end{array}$ & $\mathrm{L} / \mathrm{Y}$ & $\mathrm{C} / \mathrm{Y}$ \\
\hline 1 & PJSC "Khmilnysilmash" & 10446 & \begin{tabular}{|l|l|l}
827 & 0 \\
\end{tabular} & 86 & 9,61 & 121,5 \\
\hline 2 & $\begin{array}{l}\text { PJSC "Kalinovsky District Enterprise } \\
\text { "Agromash" }\end{array}$ & 3660 & 752 & 3671 & 0,20 & 0,99 \\
\hline 3 & $\begin{array}{l}\text { PJSC "Mohilsv-Podilsky Plant of Gas Equipment } \\
\text { and Devices" }\end{array}$ & 9302 & 554 & 1329 & 0,42 & 7,00 \\
\hline 4 & PJSC "Shargorod District Enterprise "Agromash" & 1391 & 354 & 1556 & 0,23 & 0,89 \\
\hline 5 & $\begin{array}{l}\text { PJSC "Vinnytsya Specialized Enterprise" } \\
\text { Remtechsilmash" }\end{array}$ & 3519 & 906 & 2701 & 0,33 & 1,30 \\
\hline 6 & $\begin{array}{l}\text { PJSC "Bershadsky District Enterprise } \\
\text { "Agromash" }\end{array}$ & 3280 & 84,5 & 362 & 0,23 & 9,06 \\
\hline 7 & PJSC "VinnytsyaAvtoSpetsobladnannya" & 956 & 124 & 463 & 0,27 & 2,06 \\
\hline 8 & PJSC "Hercules" & 218 & 218 & 178 & 1,22 & 1,22 \\
\hline 9 & $\begin{array}{l}\text { PJSC "Nemyrivske District Enterprise } \\
\text { "Agromash" }\end{array}$ & 2777 & 353 & 268 & 1,32 & 10,36 \\
\hline 10 & PJSC "Autoelectro equipment" & 7322 & 464 & 239 & 1,94 & 30,63 \\
\hline 11 & $\begin{array}{l}\text { PJSC Trostianetsky District Enterprise } \\
\text { "Agromash" }\end{array}$ & 870 & 4 & 684 & 0,006 & 1,27 \\
\hline 12 & PJSC "Enterprise "Medtekhnika" & 1691 & 1405 & 3691 & 0,38 & 0,46 \\
\hline 13 & PJSC "Dashivsky Repair and Mechanical Plant" & 6480 & 2200 & 18252 & 0,12 & 0,35 \\
\hline 14 & PJSC "Vinnytsia Plant" Budmash" & 65752 & 1826 & 7456 & 0,24 & 8,81 \\
\hline 15 & PJSC "Bershad Electrotechnical Plant" & 10567 & 3358 & 8390 & 0,40 & 1,26 \\
\hline 16 & PJSC "Yampilskiy Instrument-Making Plant" & 11160 & 13653 & 51733 & 0,26 & 0,21 \\
\hline 17 & PJSC "Mohyliv-Podilsky Machine-Building Plant" & 71881 & 17064 & 64754 & 0,26 & 1,11 \\
\hline 18 & PJSC "Mayak" & 63475 & 56780 & 311874 & 0,18 & 0,20 \\
\hline 19 & PJSC "Barsky Machine-Building Plant" & 60490 & 23970 & 141782 & 0,17 & 0,43 \\
\hline 20 & PJSC "Vinnytsia Research Plant" & 46571 & 4511 & 44069 & 0,10 & 1,06 \\
\hline 21 & PJSC "Kalinivskiy Machine-Building Plant" & 29467 & 25789 & 164767 & 0,16 & 0,18 \\
\hline 22 & Plasmatek PJSC & 618112 & 151738 & 1335224 & 0,11 & 0,46 \\
\hline
\end{tabular}

Source: calculated by the authors.

The main evaluation factor is the effective indicator of the functioning of enterprises - 
income (revenue) from sales of products. As a result, physical capital is the fixed assets of enterprises (at initial cost), and human capital is represented by the wage costs of employees.

It should be pointed out that such a representation of human capital is somewhat incorrect, since using only the indicator of labor costs by enterprises does not take into account the cost of knowledge, intellectual work, management work, the factors of the functioning environment and work factors are ignored. At the same time, wage costs are a universal aggregate indicator, which reflects the general tendency of economic and social conditions in the region and also in the whole country.

Using the correlation-regression method, we will analyze the impact of the cost capital (fixed assets) and the cost of wage labor for income (revenue) from the sale of enterprises. The regression equation $y=8,4238 x-19183$ (Figure 1) shows that in the absence of labor costs for hired workers $(x=0)$, income(revenue) from sales will have a negative value (19,183 thousand) UAH).

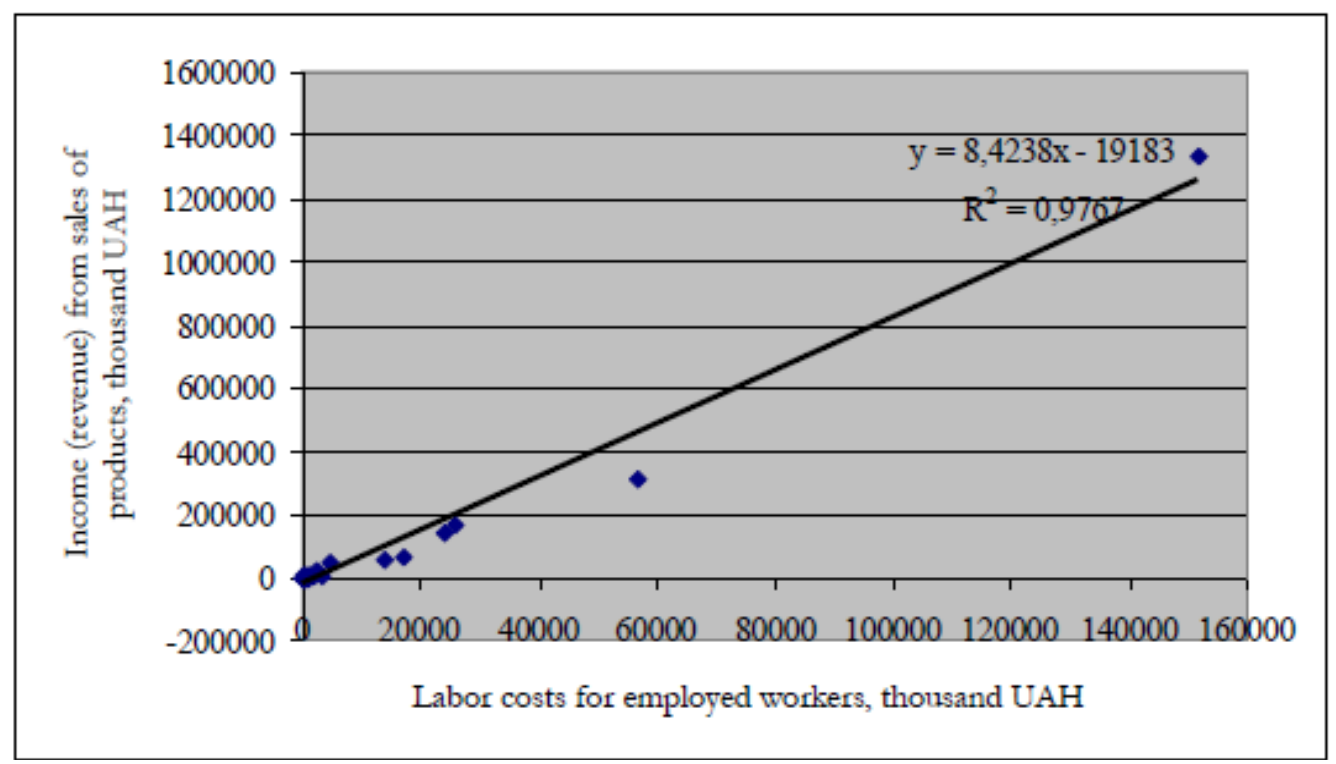

Figure 1: Dependence of income (revenues) on sales of products from labor costs of hired workers Source: built by the authors.

As a result, in order to ensure that income (revenue) from sales of products is zero (the breakeven condition is fulfilled), the minimum wage costs for wage earners should be 2277 thousand UAH.

Dependence of income (proceeds) on sales of products from capital expenditures (fixed assets) (Figure 2) has the form: $y=2,1578 x-2620,9$. In this case there is a negative value of income (proceeds) from sales of products $(-2620,9)$ provided $(x=0)$. 


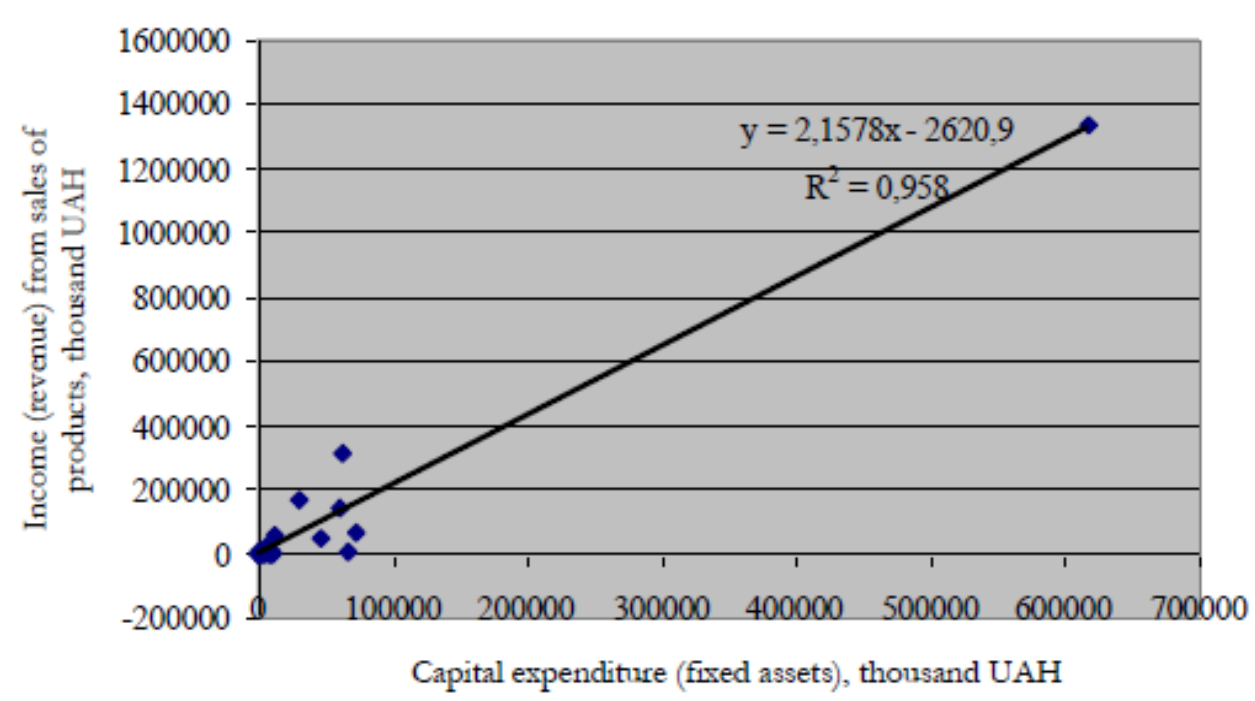

Figure 2: Dependence of income (revenue) on sales of products from capital expenditures (fixed assets) Source: built by the authors.

To achieve a break-even level of income (revenue) from the sale of products, the required cost of capital (fixed assets) should be 1215 thousand UAH.

Comparing the levels of minimum capital expenditures (fixed assets) and wages of hired workers, it can be concluded that wage labor costs are 1.87 times (2277/1215) higher than capital costs (fixed assets). The factor of human capital plays a decisive role in creating revenue (revenue) from sales of products, since the growth of profit is possible with the increase of the latter indicator, provided there is a tendency for more rapid growth of labor costs for wage workers compared with the cost of capital.

In general, based on the regression equation, there are unfavorable conditions for investing both in labor force and fixed assets, since the negative significance for both dependencies shows unproductive costs in machine building, which leads to a minimization of not only profits but also income ( proceeds from sales of products. Thus, one should estimate the level of costs influence between themselves without taking into account the values of income (revenue) from the sale of products.

For the first case, let's carry out an assessment of the impact of wage labor costs on capital expenditures (fixed assets) (Figure 3).

The regression equation $y=3.6678 \mathrm{x}-4381.3$ characterizes, on the one hand, the high density of the link between the cost of wage labor and the cost of capital (fixed assets), and on the other hand- the need to reach the wage cost labor in 1194, 5 thousand UAH to ensure the possibility of spending on capital (fixed assets), since this amount will provide a condition of break-even $(y=0)$. Thus, the negative value is 4381.3 thousand UAH. can be considered as a factor hindering both the formation of capital (fixed assets) of machinebuilding enterprises, as well as the establishment of an effective system of remuneration for hired workers. 


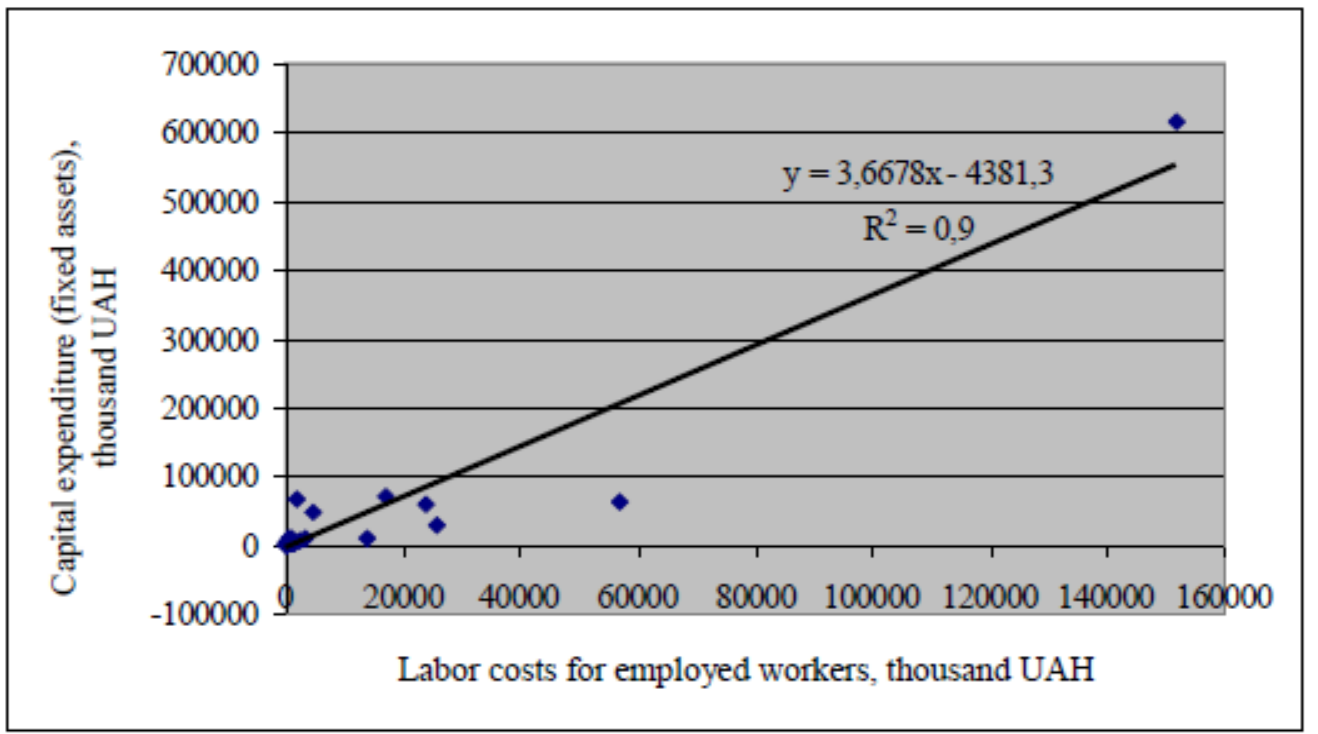

Figure 3. Dependence expenses of capital (fixed assets) on wages expenses of hired workers Source: built by the authors.

For the second case, consider the opposite dependence - the effect of capital expenditures (fixed assets) on labor costs of hired workers (Figure 4).

Unlike in the first case, the components of the regression equation have other signs, in particular a positive value of 2470.7 characterizes the guaranteed amount of labor costs for hired workers, even if the cost of capital (fixed assets) will be absent $(x=0)$.

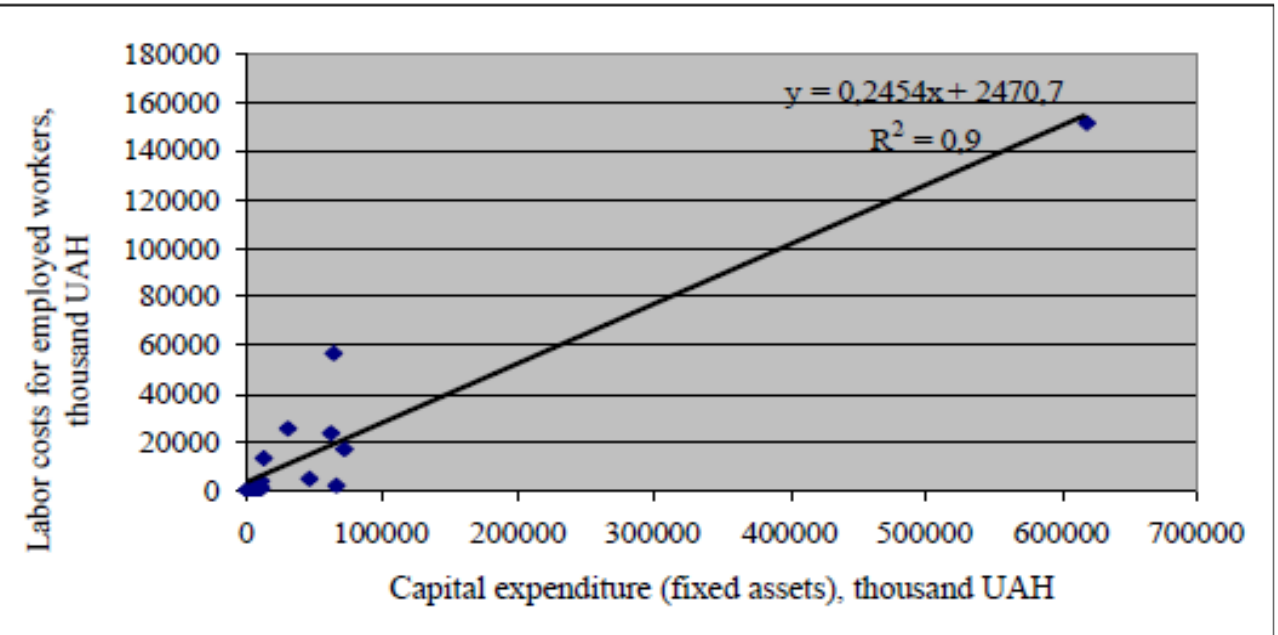

Figure 4. Dependence of labor costs on wage earners on capital expenditure (fixed assets) Source: built by the authors.

Increase of expenses on a capital (fixed assets), for example on $1 \mathrm{mln} \mathrm{UAH}$, will lead to the fact that the salaries of wage earners will be: $0.2444 \cdot 1000+2470.7=2716.1$ thousand 
UAH. Thus, we can conclude that in the present the development of the mechanical engineering of the Vinnytsia region conditions of human capital formation is crucial for the growth of physical capital by investing in fixed assets.

We propose to determine the required amount of investment in capital (fixed assets) using the method of analysis of the functioning environment [8]. The basis of this method is the calculation of the coefficients of covering the income (revenue) from the sale of labor costs of wage labor (L / Y) and the ratio of income coverage (revenue) from the sale of capital goods (fixed assets) (K/Y) (Table 1).

On the coordinate system it is necessary to put the positions of those enterprises, the coverage ratios of which are as close as possible to one (Figure 5). Thus, the positions of such entities as PJSC "Khmilnysilmash", PJSC "Avtoelektroapparatury", PJSC "Nemyrivske District Enterprise" Agromash ", PJSC" Bershadsky District Enterprise "Agromash", PJSC "Mohyliv-Podilsky Gas Equipment Plant" will not be taken into account. and devices ", PJSC" Vinnitsa plant "Budmash" and others like that.

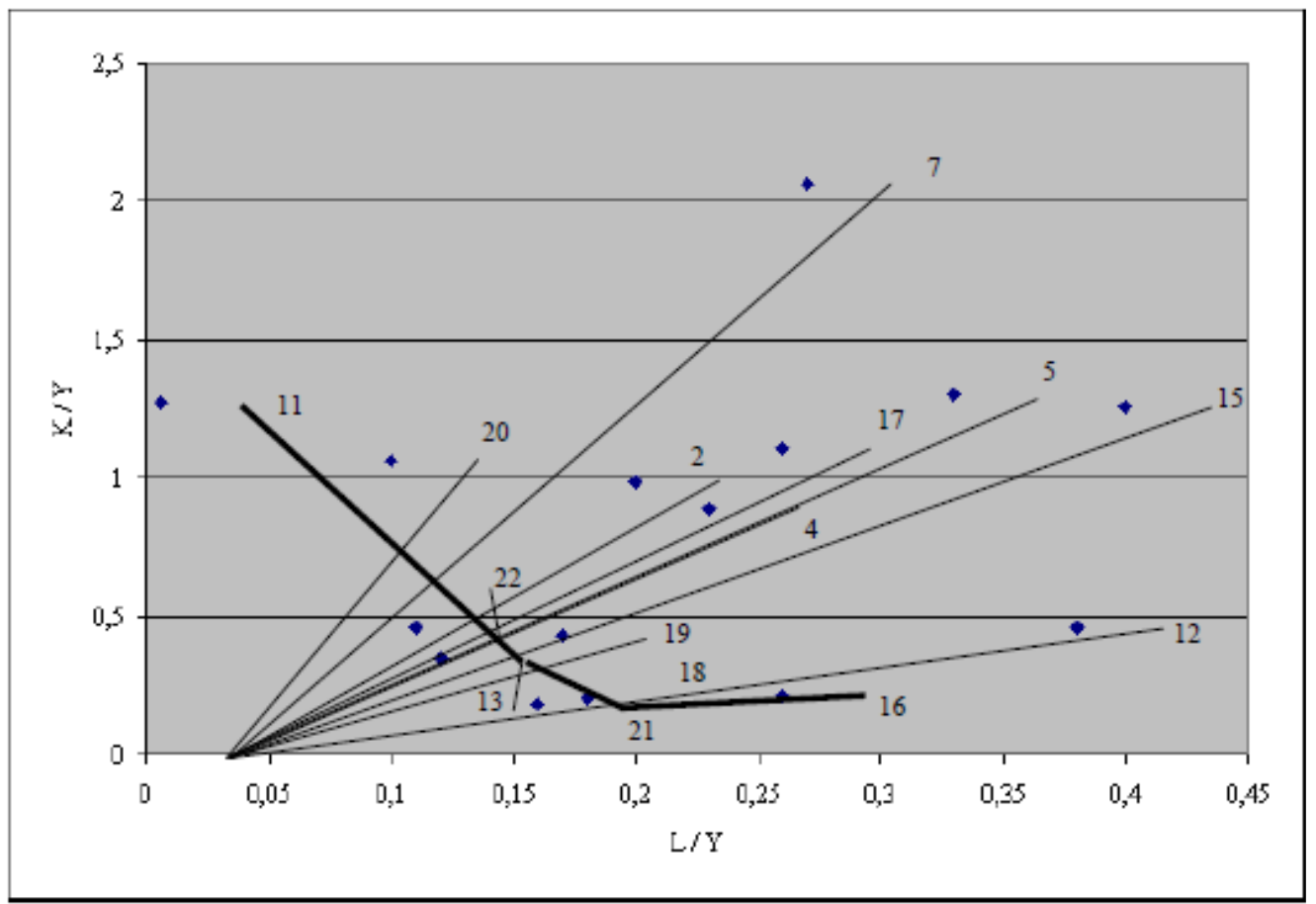

Figure 5. Analysis of functioning environment of machine-building enterprises

Source: built by the authors.

He line of technical efficiency is made up of the positions of enterprises 11 (PJSC «Trostyanetske regional enterprise Agromash »), 22 (PJSC« Plasmatek »), 13 (PJSC« Dashiv repair-mechanical factory »), 21 (PJSC« Kalinovsky machine-building plant »), 18 PJSC "Mayak"), 16 (PJSC "Yampilsky Instrument-Making Plant"). The positions of other enterprises are technically inefficient, therefore it is important for these economic entities to determine the ratio of income coverage (revenue) from the sale of capital goods (fixed 
assets) at the lines intersection 0-20, 0-7, 0-2, 0- 17, 0-4, 0-5, 0-15, 0-19, 0-12 with a line of technical efficiency (Table 2).

Table 2: Estimated values of coverage ratios for income (revenue) from sales of capital goods (fixed assets)

\begin{tabular}{|l|l|l|l|}
\hline Position & Enterprise & $\begin{array}{l}\text { Table value } \\
\text { C/Y }\end{array}$ & $\begin{array}{l}\text { Estimated } \\
\text { value of K / Y }\end{array}$ \\
\hline 7 & PJSC "VinnitsaAvtoSpetsobladnannya" & 2,06 & 0,65 \\
\hline 20 & PJSC "Vinnytsia Research Plant" & 1,06 & 0,80 \\
\hline 2 & $\begin{array}{l}\text { PJSC "Kalinovsky District Enterprise } \\
\text { "Agromash" }\end{array}$ & 0,99 & 0,55 \\
\hline 17 & PJSC "Mohyliv-Podilsky Machine-Building Plant" & 1,11 & 0,46 \\
\hline 4 & PJSC "Shargorod District Enterprise" Agromash " & 0,89 & 0,45 \\
\hline 5 & $\begin{array}{l}\text { PJSC "Vinnytsya Specialized Enterprise } \\
\text { "Remtechsilmash" }\end{array}$ & 1,30 & 0,45 \\
\hline 15 & PJSC "Bershad Electrotechnical Plant" & 1,26 & 0,40 \\
\hline 19 & PJSC "Barsky Machine-Building Plant" & 0,43 & 0,35 \\
\hline 12 & PJSC "Enterprise "Medtekhnika" & 0,46 & 0,18 \\
\hline
\end{tabular}

Source: calculated by the authors.

Based on the fact that the cost of capital (fixed assets) remains unchanged, based on the estimated ratio of income (revenue) from the sale of capital goods (fixed assets), we will determine the value of income (revenue) from the sale of products for new positions of these enterprises (Table 3).

Table 3: Estimated cost of capital (fixed assets) of machine-building enterprises

\begin{tabular}{|l|l|l|l|l|}
\hline $\begin{array}{c}\text { Posi- } \\
\text { tion }\end{array}$ & Enterprise & $\begin{array}{l}\text { Table value } \\
\text { of income } \\
\text { (revenue) } \\
\text { from sales of } \\
\text { products, ths. } \\
\text { UAH }\end{array}$ & $\begin{array}{l}\text { Estimated value } \\
\text { of income } \\
\text { (revenue) from } \\
\text { sales of } \\
\text { products, ths. } \\
\text { UAH }\end{array}$ & $\begin{array}{l}\text { betweence } \\
\text { calculated } \\
\text { and tabular } \\
\text { values, ths. } \\
\text { UAH }\end{array}$ \\
\hline 7 & PJSC "VinnitsaAvtoSpetsobladnannya" & 463 & 1471 & 1008 \\
\hline 20 & PJSC "Vinnytsia Research Plant" & 44069 & 58214 & 14145 \\
\hline 2 & $\begin{array}{l}\text { PJSC "Kalinovsky District Enterprise" } \\
\text { Agromash" }\end{array}$ & 3671 & 6654 & 2983 \\
\hline 17 & $\begin{array}{l}\text { PJSC "Mohyliv-Podilsky Machine- } \\
\text { Building Plant" }\end{array}$ & 64754 & 156263 & 91509 \\
\hline 4 & $\begin{array}{l}\text { PJSC "Shargorod District Enterprise" } \\
\text { Agromash" }\end{array}$ & 1556 & 3091 & 1535 \\
\hline 5 & $\begin{array}{l}\text { PJSC "Vinnytsya Specialized Enterprise" } \\
\text { Remtechsilmash" }\end{array}$ & 2701 & 7820 & 5119 \\
\hline 15 & PJSC "Bershad Electrotechnical Plant" & 8390 & 26417 & 18027 \\
\hline 19 & PJSC "Barsky Machine-Building Plant" & 141782 & 172829 & 31047 \\
\hline 12 & PJSC "Enterprise "Medtekhnika" & 3691 & 9394 & 5703 \\
\hline Altogether & 271077 & 442153 & 171076 \\
\hline
\end{tabular}

Source: calculated by the authors. 
Thus, the reduction coefficients of covering the income (revenue) from the sale of capital expenditures (fixed assets) (Table 2), only in nine technically inefficient enterprises (Table 3) allows you to increase income (revenue) from the sale of products by 17,106 thousand UAH. Based on the results of the research, the development of human capital through the increase in wages of employees is possible under the conditions of growth of capital (fixed assets) and income (revenue) from the sale of products, as the main conditions for the functioning of machine-building enterprises in the environment of the region functioning.

\section{Conclusions}

The conducted research allowed using the correlation-regression analysis and the use of the method of analysis of the functioning environment to determine the possibility of strengthening the development of human capital through the growth of wages. Based on data from twenty two machine-building enterprises in the Vinnytsia region, it has been found that, firstly, there is a low possibility of rising income (revenue) from sales of products due to increased investment in both human and physical capital. Secondly, the growth of the cost of capital (fixed assets) in the present conditions contributes to the possibility of increasing the cost of wage labor. Thirdly, taking into account the importance of capital (fixed assets) for the development of human capital, the amount of income (revenue) from sales of products is determined, which will allow motivating the activity of wage earners by stimulating their development in the system of achieving the effectiveness of business entities.

\section{References}

Amosov, O. Yu. and Diehtiar, A. O. (2011). Human capital formation under conditions of innovative economy: methodological aspect. Publichne upravlinnia: teoriia ta praktyka, 3(7): 164-172.

Bekker, H. S. (2003). Human behavior: an economic approach. Moscow. 672 p.

Solow, R. (1957). Technical Change and the Aggregate Production Function. The Review of Economics and Statistics, 39: 312-320. https://doi.org/10.2307/1926047.

Schultz, T. W. Investment in Human Capital: The Role of Education and of Research. New York: Free Press. $1971 \mathrm{p}$.

Kryvenko, L. V. and Ovcharenko, S. V. (2014). Conceptual foundations of human capital development in conditions of the country's competitiveness increase. Economic Annals-XXI, 1-2(1): 23-26.

Kuznetc, S. (1921). Money wages of workers and employees of the factory industry of Kharkov in 1920. Materials on labor statistics in Ukraine, 2: 53-64.

Lucas, R. (1980). Methods and Problems in Business Cycle Theory. Journal of Money, Credit and Banking, 12: 696-715.

Romer, P. M. (1986). Increasing Returns and Long-Run Growth. The Journal of Political Economy, October: 10021037.

Fedulova, L. I. and Prysiazhniuk, A. Yu. (2015). Human innovative factor in socio-economic development of Ukraine: international measuring. Economic Annals-XXI, 1-2(1): 15-19.

Financial Reporting of Machine-Building Enterprises. Available at: http://www.smida.gov.ua.

Farell, M. J. (1957). The Measurement of Productive Efficiency. Journal of the Royal Statistical Society, 120: 253281.

Yalovyi, H. K. (2015). The human capital theory as the methodological base of innovation system formati. Ekonomichnyi visnyk Natsionalnobo tekhnichnoho universytetu Ukrainy «Kyivskyi politekhnichnyi instytut», 12: 20_ 28. Available at: http://nbuv.gov.ua/UJRN/evntukpi 201512 6.

Bay, S. and Rozman, A. (2015). Human capital as a foundation for enterprise value growth. Actual Problems of 
Economics, 12(174): 248-257.

Drábek, J., Lorincová, S. and Javorčíková, J. (2017). Investing in Human Capital as a Key Factor for the Development of Enterprises. Issues of Human Resource Management, https://doi.org/10.5772/67741.

Diebolt, C. and Hippe, R. (2019). The long-run impact of human capital on innovation and economic development in the regions of Europe. Journal Applied Economics, 51(5): 542-563. https://doi.org/10.1080/00036846.2018.1495820.

Kopytova, I. and Zelinska, A. (2017). Evaluation of efficiency of activity of management staff: content and social and psychological aspects. Agricultural and Resource Economics: International Scientific E-Journal, 3(3): 28-40. Available at: http://www.are-journal.com.

Burkovska, A. and Romanchyk, M. (2016). The ensuring of the competitiveness of the enterprises through the strategic human resource management. Agricultural and Resource Economics: International Scientific E-Journal, 2(4): 43-51. Available at: http://www.are-journal.com.

Kowalewski, M. (2016). Physical activity as a form of leisure of young people in Warsaw in the context of human capital. Agricultural and Resource Economics: International Scientific E-Journal, 2(3): 31-36. Available at: http://www.are-journal.com.

$\mathrm{Xu}, \mathrm{J}$. and Wang, B. (2019). Intellectual Capital Performance of the Textile Industry in Emerging Markets: A Comparison with China and South Korea. Sustainability, 11(8): 2354. https://doi.org/10.3390/su11082354.

Xu, J. and Wang, B. (2018). Intellectual Capital, Financial Performance and Companies' Sustainable Growth: Evidence from the Korean Manufacturing Industry. Sustainability, 10(12): 4651. https://doi.org/10.3390/su10124651.

Kucharčíková A. and Mičiak M. (2018). Human Capital Management in Transport Enterprises with the Acceptance of Sustainable Development in the Slovak Republic. Sustainability, 10(7): 2530. https://doi.org/10.3390/su10072530.

Zhang, M., Zou, X. and Sha, L. (2019). Social Security and Sustainable Economic Growth: Based on the Perspective of Human Capital. Sustainability, 11(3): 662. https://doi.org/10.3390/su11030662.

MacDonald, A., Clarke, A., Huang, L. and Seitanidi, M. M. (2019). Partner Strategic Capabilities for Capturing Value from Sustainability-Focused Multi-Stakeholder Partnerships. Sustainability, 11(3): 557. https://doi.org/10.3390/su11030557.

Garrigos-Simon, F. J., Botella-Carrubi, M. D., Gonzalez-Cruz, T. F. (2018). Social Capital, Human Capital, and Sustainability: A Bibliometric and Visualization Analysis. Sustainability, 10(12): 4751. https://doi.org/10.3390/su10124751.

Kucharčíková, A., Mičiak, M. and Hitka, M. (2018). Evaluating the Effectiveness of Investment in Human Capital in E-Business Enterprise in the Context of Sustainability. Sustainability, 10(9): 3211. https://doi.org/10.3390/su10093211. 